This item was submitted to Loughborough's Research Repository by the author.

Items in Figshare are protected by copyright, with all rights reserved, unless otherwise indicated.

\title{
The impact of competitive strategies on responsive market orientation, proactive market orientation, learning orientation and organizational performance
}

\section{PLEASE CITE THE PUBLISHED VERSION}

https://doi.org/10.1080/0965254X.2014.970217

\section{PUBLISHER}

(C) Taylor \& Francis

\section{VERSION}

AM (Accepted Manuscript)

\section{PUBLISHER STATEMENT}

This work is made available according to the conditions of the Creative Commons Attribution-NonCommercialNoDerivatives 4.0 International (CC BY-NC-ND 4.0) licence. Full details of this licence are available at: https://creativecommons.org/licenses/by-nc-nd/4.0/

\section{LICENCE}

CC BY-NC-ND 4.0

\section{REPOSITORY RECORD}

Kharabsheh, Radwan A., Khalid Jarrar, and Boyka Simeonova. 2019. "The Impact of Competitive Strategies on Responsive Market Orientation, Proactive Market Orientation, Learning Orientation and Organizational Performance". figshare. https://hdl.handle.net/2134/36407. 
The impact of competitive strategies on responsive market orientation, proactive market orientation, learning orientation and organizational performance

\begin{abstract}
Drawing on the strategy implementation approach and the resource-based view of the firm, this study examines the relationships among competitive strategies (differentiation and cost leadership), responsive market orientation (RMO), proactive market orientation (PMO), learning orientation (LO) and organizational performance. The study used questionnaire survey of senior managers of 264 manufacturing and service companies in Jordan. The study employed partial least squares to test the hypotheses. Moderate but significant relationships are evident in the links between cost leadership and LO, and RMO and organizational performance. Strong and significant relationships are exhibited in the links between differentiation and RMO; differentiation and PMO; differentiation and LO and between LO and organizational performance. The results show that differentiation strategy is more important than cost leadership strategy and that LO is the most important factor for better organizational performance.
\end{abstract}

Keywords: competitive strategy; differentiation strategy; cost leadership strategy; responsive market orientation; proactive market orientation; learning orientation

Introduction

In today's economy, the business environment is dynamic. Time-based competition, shift of power to customers, massive increase in products and services selection, and new sources of competitive advantage are resulting in many organizations to become learning and market oriented in order to remain competitive (Eleri \& Morgan, 2007; Tortosa, Miguel, \& Javier, 2009; Zhang \& Duan, 2010). Several studies underlined the significance of a market orientation (MO) as a firm capability and antecedent to superior organizational performance and profitability (Akimova, 2000; Clulow, Barry, \& Gerstman, 2007; McGuinness \& Morgan, 2005). The notion of MO has been presented in the literature as the core of marketing strategy (Guo, 2002; Sørensen, 2009; Voola \& O'Cass, 2010). Also, MO is seen as one of the most creative strategic options in satisfying market needs more efficiently (Grinstein, 2008; Nwokah, 2008). This efficiency is achieved by the process of collecting information thorough market/marketing research, which is then disseminated across the organization in order to facilitate the decision-making process that will affect all market parties and will produce profits in the long range (Kohli \& Jaworski, 1990; Narver \& Slater, 1990).

Researchers argued that there is a connection between Porter's three competitive strategies and MO (Olson, Slater, \& Hult, 2005; Slater \& Narver, 1996). Day (1990) contended that MO as a firm capability is composed mainly of two interrelated parts: customer orientation represented by differentiation or focus strategy, and a competitor orientation represented by low-cost strategy. Frambach, Prabhu, and Verhallen (2003) indicated that differentiation and/or cost leadership strategies have an effect on the level of MO in a firm. Voola and O'Cass (2010) affirmed the positive relationship between competitive strategies and $\mathrm{MO}$ but also suggested that other capabilities may also play an important role such as learning orientation (LO), which is the ability of the firm to generate, spread and make use of knowledge (Farrell, Oczkowski, \& Kharabsheh, 2008). In addition, there has been a lack of clarity regarding the relative contributions of a market and LO to organizational performance. For example, Baker and Sinkula (1999b, p. 422) stated that in the absence of one or the other, it would be better for a firm to have a strong market orientation.' Conversely, Baker and Sinkula (1999a, p. 305) found that $\mathrm{MO}$ does not have a direct effect on organizational performance. Farrell (2000) found that LO positively effects organizational performance, while Farrell and Oczkowski (2002) found overall support that $\mathrm{MO}$ has a stronger relationship with organizational performance than does LO. SantosVijande, Sanzo-Pe'rez, A ' Ivarez-Gonza'lez, and Va'zquez-Casielles (2005a, 2005b) found a positive 
relationship between $\mathrm{MO}$ and organizational performance, but no effect for $\mathrm{LO}$ and organizational performance.

The study extends the work of Voola and O'cass (2010) and contributes to the strategy implementation literature by examining the effects of competitive strategies on responsive market orientation (RMO), proactive market orientation (PMO) and LO therefore including learning capabilities into the analysis. The study also builds on Farrell et al. (2008) and Farrell and Oczkowski (2002) and tests the relative contribution of RMO, PMO and LO on organizational performance. The purpose is to show that competitive strategies have a significant effect on $\mathrm{MO}$ and LO and both LO and $\mathrm{MO}$ have a significant effect on organizational performance. Further, the paper aims to examine the relative contribution of RMO, PMO and LO on organizational performance.

The study model

There is debate on whether organizational dimensions affect competitive strategies (strategy formulation) or whether competitive strategies affect organizational dimensions (strategy implementation) (Noble \& Mokwa, 1999; Prahalad \& Bettis, 1986). The strategy formulation approach views organizational variables as antecedents to strategy on the basis that managerial action is founded on underlying beliefs, behaviours and cognitive maps (Foil \& Huff, 1992; Homburg, Krohmer, \& Workman, 2004), whereas the strategy implementation approach involves viewing strategy as affecting organizational dimensions, or organizational dimensions are adapted to strategy, which then results in higher firm performance (Homburg et al., 2004). With the advent of the Resource Based (RB) theory (Barney, 1991; Day, 1994), firm capabilities are increasingly being viewed as organizational dimensions that must be developed and deployed to implement a particular competitive strategy effectively. The RB theory adopts an inside-out approach to strategy, taking the position that internal firm factors explain more variance in firm performance than do external industry-related factors (Barney, 1991; O'Cass \& Ngo, 2007; Wernerfelt, 1984). Furthermore, O'Cass and Ngo (2007) showed that strategy drives MO. Thus, if MO and LO are a firm's capabilities, then the strategy the firm develops and seeks to pursue requires implementation. MO and LO then provide the mechanisms through which strategy is enacted through its possession and appropriate deployment. Finally, Slater and Narver (1996) argued that successful execution of a strategy is facilitated by MO while Frambach et al. (2003) found that a firm's differentiation strategy and/or cost leadership strategy influence the extent of MO. Figure 1 depicts the study model.

Responsive and PMO

Narver, Slater, and MacLachlan (2000, p. 7) defined the concept of PMO as 'the attempt to understand and satisfy customers' latent needs'. Their development of PMO was based on Jaworski and Kohli's (1996) and Slater and Narver's (1995) distinction between customers expressed and latent needs. Expressed needs are those needs that the customers are aware of and consequently can express, whereas latent needs are needs that the customers are unaware of and reside in the subconscious of the customers. Voola and O'Cass (2010) contended that 'the treatment of RMO and PMO as distinct constructs is consistent with empirical research and that RMO and PMO are statistically related but distinct constructs'. While RMO is centred on expressed needs, PMO is centred on latent needs.

Hypothesis development

The core idea of differentiation strategy is to improve product/service value by 'adding' advantages that are perceived industry wide as unique by customers. This can be accomplished through a brand name image, technology, services or product properties. Thus, it can be argued that a differentiation strategy is compatible with MO's extrinsic focus on determining customer's expressed needs and satisfying them better than competitors (Slater \& Narver, 1996). Therefore, a differentiation strategy involves deep collection, dissemination and analysis of market force and customer information, and thus affects MO directly. Many scholars have found that a differentiation strategy is related positively 
to marketing's influence (Frambach et al., 2003; Homburg et al., 2004; Narver \& Slater, 1990; Pelham \& Wilson, 1996; Slater \& Narver, 1996; Voola \& O'Cass, 2010). This leads to the following hypothesis: $\mathrm{H} 1$ : Differentiation strategy is positively related to RMO.

The cost leadership strategy attempts to lower costs while being better and faster in providing more value than a competitor. It aims to decrease internal efficiency into lower costs for the buyers. It is centred on value, economies of scale, and scope. This brings about reductions in product costs, R\&D, services, sales personnel or communication. A market-oriented firm can be successful by determining what cost advantages should be transmitted to their target market with just sufficient market intelligence generation, dissemination and responsiveness to understand where customers' needs are going and what features of the firm's activities can be reduced without missing with customers' perceived quality (Frambach et al., 2003). Several studies have underlined the significance of cost leadership strategy and its positive effects on MO (Frambach et al., 2003; Slater \& Narver, 1996; Voola \& O'Cass, 2010). This leads to the following hypothesis:

$\mathrm{H} 2$ : Cost leadership strategy is positively related to RMO.

Developing an offer that generates superior value for customers requires knowledge of their expressed and anticipating latent needs in order to develop PMO. The expressed customer needs are easy to collect and available to all competitors in the marketplace (Frank, Keßler, \& Korunka 2010), and this will result in competitors producing similar products and services, offering the same benefits and solutions (Narver, Slater, and MacLachlan 2004), with overemphasis on their present needs (Baker \& Sinkula, 2007). Consequently, customers recognize no differences in the value among products and/or services. Slowly eliminating the factor of differentiation, the price-based competition turns out to be unavoidable as the firms find themselves engaged in cut-throat price competition in the attempt to create superior value for their customers (Narver et al. 2004). Thus, a differentiation strategy through PMO allows for an understanding of customers' latent needs and scanning the market for new opportunities, and uncovering future trends in the market (Zhang \& Duan, 2010). This leads to the following hypothesis:

H3: Differentiation strategy is positively related to PMO.

PMO consists of three interrelated parts: value creation, change and leadership (Barlow \& Sarin, 2003; Consuegra, Molina, \& Esteban, 2007). PMO attempts to syndicate a firm's market understanding with real potentials distant from its current experience (Tsai, Chou, \& Kuo, 2007; Voola \& O'Cass, 2010). Therefore, by applying cost leadership strategy in order to unveil new opportunities in the market, PMO is a necessary requirement to enhance the efficacy and effectiveness of a firm's internal competencies (Bodlaj, 2011). This implies that firms will engage with industry and customers to discover, understand and satisfy their customers' latent needs. Thus, providing better pricing than competitors based on cost reduction should be done by examining the production process through customers' eyes. This leads to the following hypothesis:

$\mathrm{H} 4$ : Cost leadership strategy is positively related to PMO.

A differentiation strategy affects LO on the basis that learning activities are likely to be influenced by strategic choices (Slater \& Olson, 2001). A differentiation strategy requires learning capabilities that can only exist through LO. First, a differentiation strategy necessitates a commitment to learning. Companies that are not committed to learning may as well stop learning after they achieve success. Most importantly, commitment to learning is associated with a long-term strategic orientation. Second, a shared vision is a reflection of a firm's differentiation strategy. Verona (1999) stressed that without a shared vision, learning by members of an organization is less likely to be meaningful. A shared vision coordinates the focus of various departments and enhances the quality of learning. Finally, a differentiation strategy affects a firm's open mindedness which is important for a firm to unlearn old knowledge and keep progressing into the future. Firms must cope with rapidly changing 
technology and turbulent markets. The rate of knowledge obsolescence is high in most sectors. This leads to the following hypothesis:

H5: Differentiation strategy is positively related to LO.

A cost leadership strategy seeks to reduce overall cost of the firm through numerous ways: by finding cheaper ways of doing the same, finding newer products that can provide more value with less and so on. In order to achieve this, companies have to learn better and faster than competitors. Firms that follow a cost leadership strategy need to imitate competitors and do the same much cheaper, and therefore learning here becomes critical. There is a need to be committed to learning, have a shared vision among employees concerning the need to continuously reduce cost and be able to unlearn old knowledge and substitute it with newer ways that are more efficient. Therefore, LO helps in transmitting the benefits of a cost leadership strategy to firm performance. This leads to the following hypothesis:

H6: Cost leadership strategy is positively related to LO.

RMO, PMO, LO and organizational performance

The key premise of the RB theory is that competitive advantage lies in the heterogeneous firm-specific capabilities held by firms (Montgomery \& Wernerfelt, 1988). Moreover, RB theory contends that capabilities are the most important source of an organization's success (Day, 1994). Firm capabilities are difficult to duplicate (Dierickx \& Cool, 1989). Atuahene-Gima, Slater, and Olson (2005) conceptualized RMO, PMO and LO as capabilities. Numerous studies found a positive relationship between MO and organizational performance (Cano, Carrillat, \& Jaramillo, 2004; Day, 1994). However, these conceptualizations of $\mathrm{MO}$ viewed it primarily as a responsive capability (RMO), attempting only to understand customers' expressed needs and satisfying them (Kohli \& Jaworski, 1990; Narver \& Slater, 1990). Still, however, based on the previous discussion, a positive relationship is expected to be found between RMO and organizational performance. This leads to the following hypothesis:

$\mathrm{H7}$ : RMO is positively related to organizational performance.

While MO can be a source of competitive advantage when it is rare in a firm's industry (Barney, 1991), it becomes imitable in the long run. Narver et al. (2000) argued that with the widespread research on $\mathrm{RMO}$, firms are increasingly investing in being market oriented in the traditional notion of RMO. Therefore, in the long run, competitors imitate it (Narver et al., 2000). This is why Narver et al. (2004) argued that to develop and maintain a competitive advantage, firms increasingly must complement RMO with PMO. Furthermore, Voola and O'Cass (2010) argued that to understand and discover latent needs and to respond with new solutions, proactively market-oriented firms are more likely to scan the markets more widely than are firms that focus on RMO and work integrally with lead customers. Further, Voola and O'Cass (2010) contended that firms adopting PMO are more likely to understand not only the expressed needs but the latent needs of the customers, allowing firms to uncover new market opportunities, all of which affect customer value and firm performance. This leads to the following hypothesis:

$\mathrm{H} 8: \mathrm{PMO}$ is positively related to organizational performance.

Numerous studies demonstrated that LO leads to high levels of organizational performance (Baker \& Sinkula, 1999a; Calantone, Cavusgil, \& Zhao, 2002; Celuch, Kasouf, \& Peruvemba 2002; Farrell \& Oczkowski, 2002; Farrell et. al., 2008). LO allows the firm to seek and exploit opportunities and/or neutralize threats in a firm's environment. Day (1994) and Dickson (1992) argued that that LO enables a firm to more successfully understand the needs of customers better than its competitors. LO also allows companies to question long-held assumptions about its mission, capabilities or strategy (Slater \& Narver, 1995). This leads to the following hypothesis:

H9: LO is positively related to organizational performance. 


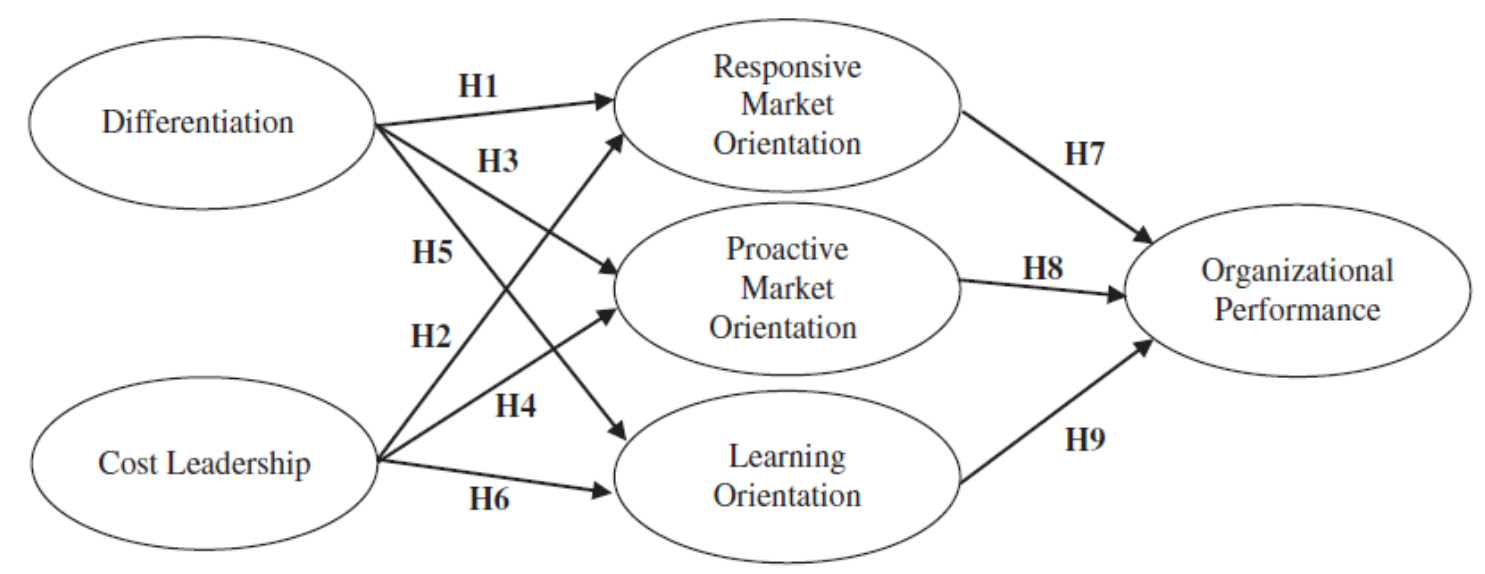

Figure 1. The study model.

\section{Method}

Data collection

The study utilized a self-administered questionnaire survey of all Jordanian companies listed on the Jordanian stock market. The study used the Jordanian Ministry of Industry and Trade's classification for firms' size according to the number of employees. According to this classification, firms that have 10-49 employees are small firms, those that have 50- 249 employees are medium firms and those that have more than 250 are considered large firms (Ministry of Industry and Trade, 2014). It was found that $21 \%$ of participating firms were small, $36 \%$ were medium firms and the remaining $43 \%$ were large firms. Also, $53 \%$ of the firms were from the service sector while the remaining $47 \%$ were from the manufacturing sector. Table 1 shows the distribution of firms according to sector and nature of business. Senior managers of the companies, and heads of units and departments were informed of the nature of the study and its objectives and were assured of the anonymity of their personal and organizational data. In total, 264 usable questionnaires were returned. Data collectors gave managers the questionnaires and returned at the end of the working day or some agreed time. Managers were asked if they wished to obtain a copy of the executive summary of the results once the study is completed. Due to the personal nature of the data collection, there were no missing data points.

Measures

LO was measured using the Baker and Sinkula (1999a) measure, which focuses upon commitment to learning, open-mindedness and shared vision. RMO was measured using Deshpande', Farley, and Webster's (1993) measure; PMO by Narver et al.'s (2004) measure and differentiation and cost leadership competitive strategies by Frambach et al.'s (2003) measures. The study measured organizational performance through five dimensions of business performance relative to all other competitors in the organization's principal served market segment over the past year: customer retention; new product success; sales growth; return on investment and overall performance. The study examines these measures individually and as five indicators in a five-item scale named business performance. 
Table 1. Distribution of firms according to sector.

Firms' sector

Number of firms

Software development

Commercial banks

Hospitals

7

Telecommunication $\quad 37$

Transportation 25

Universities

General 16

Fast moving consumer goods $\quad 55$

$\begin{array}{lr}\text { Pharmaceutical firms } & 12\end{array}$

$\begin{array}{lr}\text { Mining and extraction firms } & 7\end{array}$

$\begin{array}{lr}\text { Garment production } & 20\end{array}$

Electricity production and distribution 3

$\begin{array}{lr}\text { Chemicals } & 27\end{array}$

$\begin{array}{lr}\text { Total } & 264\end{array}$

Analysis procedures

In order to test the model, we have conducted partial least squares (PLS) analysis. PLS analysis is used as it is suitable for exploratory studies with newly developed constructs. PLS is a 'second generation regression model that combines a factor analysis with linear regressions, making only minimal distribution assumptions' (Homburg et al., 2004, p. 71). PLS allows for testing second-order constructs and is suitable for complex models with numerous exogenous and endogenous variables.

Measurement model

We measured the reliability and validity of the model. We checked the internal reliability of our model by measuring Cronbach's a. The Cronbach's as for our constructs range between 0.71 and 0.93 , thus showing satisfactory levels of reliability. The Cronbach's as for all the constructs are presented in Table 2. Subsequently, a confirmatory factor analysis was conducted to assess convergent and discriminant validity. First, the factor loadings were examined. A number of items were deleted because of low factor loadings, shown in Table 3. All other factor loadings are greater than 0.6 which shows acceptable convergent validity (Hair Jr., Hult, Ringle, \& Sarstetd, 2014). Additionally, to address convergent validity, average variance extracted (AVE) was measured. The results are presented in Table 4. Following Fornell and Larcker (1981), AVE should be greater than 0.5 in order to ensure adequate convergent validity. As shown in Table 4, all constructs exhibited AVE greater than 0.5. For discriminant validity, the square root of AVE for each construct is compared to the inter-correlations between the construct. Thus, it is expected that the square root of the AVE for the construct should be greater than the correlations between that construct and the other constructs of the model (Fornell \& Larcker, 1981). The discriminant validity results are presented in Table 5.

Table 2. Reliability results.

\begin{tabular}{lc}
\hline Construct & Cronbach's $\alpha$ \\
\hline Cost leadership & 0.71 \\
Differentiation & 0.86 \\
LO & 0.93 \\
Organizational performance & 0.91 \\
PMO & 0.84 \\
RMO & 0.86 \\
\hline
\end{tabular}


Table 3. Items deleted due to low factor loadings.

\begin{tabular}{lc}
\hline Item deleted & Factor loading \\
\hline OM2 & 0.13 \\
SV6 & 0.13 \\
CLT5 & 0.2 \\
PMO5 & 0.32 \\
OM1 & 0.35 \\
\hline
\end{tabular}

Table 4. AVE results.

\begin{tabular}{lc}
\hline Construct & AVE \\
\hline Cost Leadership & 0.53 \\
Differentiation & 0.70 \\
LO & 0.52 \\
Organizational performance & 0.74 \\
PMO & 0.51 \\
RMO & 0.55 \\
\hline
\end{tabular}

Table 5 shows the inter-correlations between the constructs, and on the diagonal in bold are presented the values of the square root of AVE. From the results it appears that two sets of constructs exhibited high inter-correlations, which is a sign of their strong causal relationship (Hau, Kim, Lee, \& Kim, 2013). These are the pair of constructs between LO and organizational performance; and between PMO and RMO. However, the consecutive items for each construct load higher on their own constructs and the square root of AVE are greater than their inter-correlations suggesting adequate discriminant validity.

Table 5. Discriminant validity results.

\begin{tabular}{|c|c|c|c|c|c|c|}
\hline & $\begin{array}{c}\text { Cost } \\
\text { Leadership }\end{array}$ & Differentiation & LO & $\begin{array}{l}\text { Organizational } \\
\text { performance }\end{array}$ & PMO & RMO \\
\hline Cost Leadership & 0.73 & & & & & \\
\hline Differentiation & 0.42 & 0.84 & & & & \\
\hline Learning orientation & 0.34 & 0.65 & 0.72 & & & \\
\hline $\begin{array}{l}\text { Organizational } \\
\text { performance }\end{array}$ & 0.3 & 0.6 & 0.71 & 0.86 & & \\
\hline PMO & 0.36 & 0.62 & 0.62 & 0.54 & 0.71 & \\
\hline RMO & 0.41 & 0.7 & 0.71 & 0.64 & 0.72 & 0.74 \\
\hline
\end{tabular}

Structural model

To test the structural model and the hypotheses, path coefficient analysis and bootstrapping procedure with 5000 re-samplings were performed. The results are provided in Figure 2 . As part of the analysis, the coefficient of determination is assessed (R 2). R 2 for RMO is 0.52 , for PMO is 0.41 , for LO is 0.43 and for organizational performance is 0.54 . This means that the variance in the dependent variables is explained by the independent variables by $52 \%, 41 \%, 43 \%$ and $54 \%$, respectively. The next step is to assess the path coefficients and their significance levels. The findings support our proposed model except the links between cost leadership and RMO, cost leadership and 
PMO, and PMO and organizational performance. Moderate but significant relationships are evident in the links between cost leadership and LO, and RMO and organizational performance. Strong significant relationships are exhibited in the links between differentiation and RMO; differentiation and PMO, differentiation and LO, and between LO and organizational performance. This shows that differentiation strategy is more important than cost leadership strategy and that LO is the most important factor for better organizational performance. A summary of the hypotheses and the results is presented in Table 6.

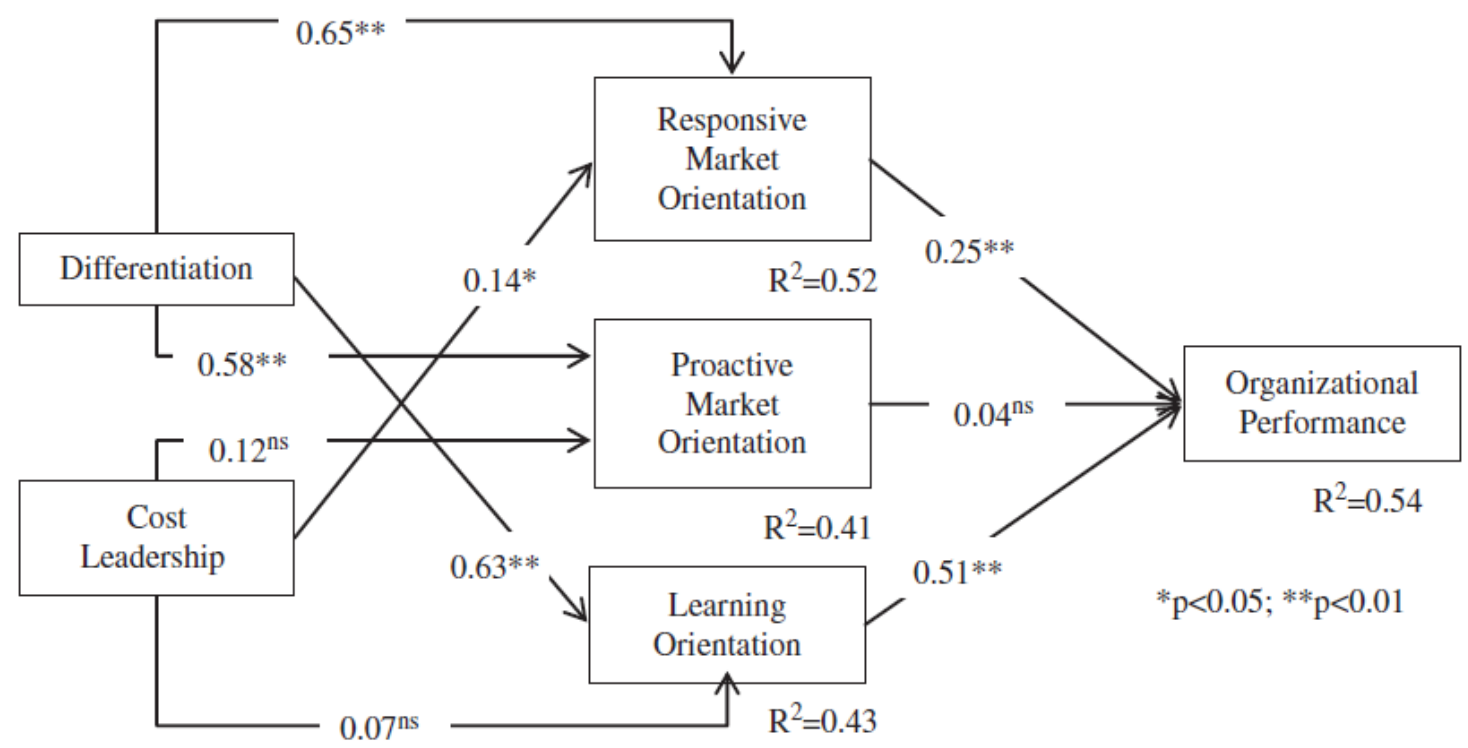

Figure 2. PLS analysis results.

Table 6. Summary of the hypotheses and the results.

\begin{tabular}{ll}
\hline Hypothesis & Result \\
\hline H1: Differentiation strategy is positively related to RMO & Supported \\
H2: Cost leadership strategy is positively related to RMO & Supported \\
H3: Differentiation strategy is positively related to PMO & Supported \\
H4: Cost leadership strategy is positively related to PMO & Not Supported \\
H5: Differentiation strategy is positively related to LO & Supported \\
H6: Cost leadership strategy is positively related to LO & Not Supported \\
H7: RMO is positively related to organizational performance & Supported \\
H8: PMO is positively related to organizational performance & Not Supported \\
H9: LO is positively related to organizational performance & Supported \\
\hline
\end{tabular}

Discussion and conclusions

This study is important in many ways. This study is grounded in the strategy implementation research. It integrates the strategy implementation approach and the RB theory to examine the role of two key firm marketing and learning capabilities (RMO, PMO and LO) in the competitive strategies-firm performance relationship. The study extends the work of Voola and O'cass (2010) and contributes to the strategy implementation literature by examining the effects of competitive strategies on RMO, PMO and LO. The study also builds on Farrell et al. (2008) and Farrell and Oczkowski (2002) and tests the relative contribution of RMO, PMO and LO on organizational performance. 
The findings essentially confirm that a differentiation strategy does have a positive and significant impact on PMO, RMO and $\mathrm{LO}(\mathrm{H} 1, \mathrm{H} 3$ and $\mathrm{H} 5)$. This is somewhat understandable in the sense that a differentiation strategy requires more understanding and knowledge of customers, markets and competitors while cost leadership requires less emphasis on the outside. In Jordan, numerous firms collect and disseminate knowledge on customers, competitors and market forces using the services of international companies such as ACNielsen, Ipsos and ESOMAR. This is especially widespread in banks, pharmaceuticals and fast moving consumer goods firms which are either international or have a high degree of international engagement and where competition is very intense. The findings also showed that a cost leadership strategy only has a significant and positive impact on RMO (H2), but no significant impact on RMO and LO ( $\mathrm{H} 4$ and $\mathrm{H6} 6$ ). Cost leadership strategy attempts to lower costs while being better and faster in providing more value than a competitor at the same time. It also aims to decrease internal efficiency into lower costs for the buyers. It is centred on value, economies of scale, and scope. Cost leadership strategy, therefore, has more focus on the production of goods and services (internal focus) and focuses less on customers and market forces. For example, certain manufacturing firms - i.e., mining and extraction - focus heavily on cost cutting and internal control and less on technology. With regards to the impact of a PMO, RMO and LO on organizational performance, the study found that RMO and LO have a positive and significant impact on organizational performance ( $\mathrm{H} 7$ and $\mathrm{H}$ 9, respectively) with LO having a greater impact. The study found no significant impact of RMO on organizational performance (H8). This is consistent with Day (1994), Dickson (1992), Sinkula (1994); Slater and Narver (1995); Senge (1990) and Barney (1991) who found that that LO leads to superior outcomes, such as new product success, superior customer retention and superior growth and/or profitability, and can be a source of a sustained competitive advantage.

\section{Implications for mangers}

There are important implications for this study. The study presented managers with empirical evidence on the capacity of firm capabilities in the competitive strategies- performance relationships. Managers need to understand that building competitive advantage goes through firm learning and market capabilities. Therefore, managers need to develop competitive strategies and at the same time further develop firm capabilities as a valid route to competitive advantage. Also, while our results clearly demonstrate the superiority of $\mathrm{LO}$ over $\mathrm{PMO}$ and RMO, we do not advocate that firms abandon a RMO and PMO entirely. An LO may be necessary to facilitate organizational learning. Indeed, SantosVijande et al. (2005b, p. 198) stated that 'learning orientation is also capable of promoting another type of valuable organisational resource such as the development of long-term relationships with strategic clients.' This is supported by findings that a 'firm that possesses a culture based on learning will tend to generate more easily feelings of trust and effective commitment to its strategic clients.' Whereas Bell, Whitwell, and Lukas (2002, p. 79) argued that MO and LO 'help to explain the critical organisational capability of market sensing . . . [and] both encompass relationships and interdependencies between individuals and groups.' Thus, Baker and Sinkula (1999b, p. 421) argue that a MO, without a strong LO, may lead to 'more imitative development that can sustain performance but is less likely to lead to the type of competitive advantage that will build market share' (Baker \& Sinkula, 1999b, p. 422).

\section{References}

Akimova, I. (2000). Development of market orientation and competitiveness of Ukrainian firms. European Journal of Marketing, 34, 1128-1148.

Atuahene-Gima, K., Slater, S. F., \& Olson, E. M. (2005). The contingent value of responsive and proactive market orientations for new product program performance. Journal of Product Innovation Management, 22, 464-482.

Baker, W. E., \& Sinkula, J. M. (1999a). Learning orientation, market orientation and innovation: Integrating and extending models of organizational performance. Journal of Market Focussed 
Management, 4, 295-308.

Baker, W. E., \& Sinkula, J. M. (1999b). The synergistic effect of market orientation and learning orientation on organizational performance. Journal of the Academy of Marketing Science, 27, 411-427.

Baker, W. E., \& Sinkula, J. M. (2007). Does market orientation facilitate balanced innovation programs? An organizational learning perspective. Journal of Product Innovation Management, 24, 316-334.

Barlow, S., \& Sarin, S. (2003). From market driven to market driving: An alternate paradigm for marketing in high technology industries. Journal of Marketing Theory and Practice, 11, 13-24.

Barney, J. B. (1991). Firm resources and sustained competitive advantage. Journal of Management, 17, 99-120.

Bell, S. J., Whitwell, G. J., \& Lukas, B. A. (2002). Schools of thought in organizational learning. Journal of the Academy of Management Science, 30, 70-86.

Bodlaj, M. (2011). The impact of responsive and proactive market orientation on innovation and business performance. Economic and Business Review, 12, 241-261.

Calantone, R. J., Cavusgil, S. T., \& Zhao, Y. (2002). Learning orientation, firm innovation capability, and firm performance. Industrial Marketing Management, 31, 515-524.

Cano, C., Carrillat, F., \& Jaramillo, F. (2004). A meta-analysis of the relationship between market orientation and competitive performance: Evidence from five continents. International Journal of Research in Marketing, 21, 179-200.

Celuch, K. G., Kasouf, C. J., \& Peruvemba, V. (2002). The effects of perceived market and learning orientation on assessed organizational capabilities. Industrial Marketing Management, 31, 545-554.

Clulow, V., Barry, C., \& Gerstman, J. (2007). The resource-based view and value: The customerbased view of the firm. Journal of European Industrial Training, 31, 19-35.

Consuegra, D. M., Molina, A., \& Esteban, A. (2007). An integrated model of price, satisfaction and loyalty: An empirical analysis in the service sector. Journal of Product \& Brand Management, 16, 459-468. doi:10.1108/10610420710834913

Day, G. (1990). Market driven strategy: Process for creating value. New York: The Free Press.

Day, G. S. (1994). The capabilities of market driven organizations. Journal of Marketing, 58, 37-51. Deshpande', R., Farley, J. U., \& Webster, F. E. (1993). Corporate culture, customer orientation, and innovativeness in Japanese firms: A quadrant analysis. Journal of Marketing, 57, 23-37.

Dickson, P. R. (1992). Toward a general theory of competitive rationality. Journal of Marketing, 56, 69-83.

Dierickx, I., \& Cool, K. (1989). Asset stock accumulation and sustainability of competitive advantage. Management Science, 35, 1504-1511.

Eleri, R., \& Morgan, E. (2007). In pursuit of the 'ideal approach' to successful marketing strategy implementation. European Journal of Marketing, 41, 659-677.

Farrell, M. A. (2000). Developing a market-oriented learning organisation. Australian Journal of Management, 25, 201-222.

Farrell, M. A., \& Oczkowski, E. (2002). Are market orientation and learning orientation necessary for superior organizational performance? Journal of Market-Focused Management, 5, 197-217. Farrell, M., Oczkowski, E., \& Kharabsheh, R. (2008). Market orientation, learning orientation and organizational performance in international joint ventures. Asia Pacific Journal of Marketing and Logistics, 20, 289-308.

Foil, C. M., \& Huff, A. S. (1992). Maps for managers: Where are we? Where do we go from here? Journal of Management Studies, 29, 267-285.

Fornell, C., \& Larcker, D. F. (1981). Evaluating path analysis models with unobservable variables and measurement error. Journal of Marketing Research, 18, 39-50.

Frambach, R. T., Prabhu, J., \& Verhallen, T. M. (2003). The influence of competitive strategy on new product activity: The role of market orientation. International Journal of Research in 
Marketing, 20, 377-397.

Frank, H., Keßler, A., \& Korunka, C. (2010). Market orientation and its impact on performance dimensions of family firms. In E. Hadjielias \& T. Barton (Eds.), Long term perspectives on family business. Theory - practice - policy (pp. 98-99). Lancaster: Lancaster University Management School.

Grinstein, A. (2008). The relationships between market orientation and alternative strategic orientations: A meta analysis. European Journal of Marketing, 40, 115-134.

Guo, C. (2002). Market orientation and business performance: A framework for service organization. European Journal of Marketing, 36, 1154-1163.

Hair, J. F. jr, Hult, G. T. M., Ringle, C., \& Sarstetd, M. (2014). A primer on partial least squares structural equation modeling (PLS-SEM). Thousands Oaks, CA: SAGE Publications.

Hau, Y. S., Kim, B., Lee, H., \& Kim, Y.-G. (2013). The effects of individual motivations and social capital on employees' tacit and explicit knowledge sharing intentions. International Journal of Information Management, 33, 356-366.

Homburg, C., Krohmer, H., \& Workman, J. P. (2004). A strategy implementation perspective of market orientation. Journal of Business Research, 57, 1331-1340.

Jaworski, B., \& Kohli, A. (1996). Market orientation: Review, refinement, and roadmap. Journal of Market-Focused Management, 1, 119-135.

Kohli, A., \& Jaworski, B. (1990). Market orientation: The construct, research propositions, and managerial implications. Journal of Marketing, 54(2), 1-18.

McGuinness, T., \& Morgan, R. (2005). The effect of market and learning orientation on strategy dynamics: The contributing effect of organizational change capability. European Journal of Marketing, 39, 1306-1326.

Ministry of Industry and Trade. (2014). Companies' laws and its modifications. Retrieved from http://www.mit.gov.jo/tabid/244/.aspx

Montgomery, C., \& Wernerfelt, B. (1988). Diversification, Ricardian rents and Tobin's q. RAND Journal of Economics, 19, 623-632.

Narver, J. C., \& Slater, S. F. (1990). The effect of a market orientation on competitive profitability. Journal of Marketing, 54, 20-34.

Narver, J. C., Slater, S. F., \& MacLachlan, D. L. (2000). Total market orientation, business performance and innovation (Report \#00.16). Cambridge, MA: Marketing Science Institute. Narver, J. C., Slater, S. F., \& MacLachlan, D. L. (2004). Responsive and proactive market orientation and new-product success. The Journal of Product Innovation Management, 21, 334-347.

Noble, C. H., \& Mokwa, M. P. (1999). Implementing marketing strategies; developing and testing managerial theory. Journal of Marketing, 54, 20-35.

Nwokah, N. G. (2008). Strategic market orientation and business performance: The study of food and beverages organizations in Nigeria. European Journal of Marketing, 42, 279-286.

O'Cass, A., \& Ngo, L. V. (2007). Balancing external adaptation and internal effectiveness:

Achieving better brand performance. Journal of Business Research, 60, 11-20.

Olson, E. M., Slater, S. F., \& Hult, T. (2005). The performance implications of fit among business strategy, marketing organization structure, and strategic behavior. Journal of Marketing Pelham, A., \& Wilson, D. (1996). A longitudinal study of the impact of market structure, firm structure, strategy, and market orientation culture on dimensions of small-firm performance. Journal of the Academy of Marketing Science, 24, 27-43.

Prahalad, C., \& Bettis, A. (1986). The dominant logic: A new linkage between diversity and performance. Strategic Management Journal, 7, 485-501.

Santos-Vijande, M. L., Sanzo-Pe'rez, M. J., a'lvarez-Gonza'lez, L., \& Va'zquez-Casielles, R. (2005a). Effects of market orientation on business strategic behaviour. Journal of Strategic Marketing, $13,17-42$.

Santos-Vijande, M. L., Sanzo-Pe'rez, M. J., A ' Ivarez-Gonza'lez, L. I., \& Va'zquez-Casielles, R. V. 
(2005b). Organisational learning and market orientation: Interface and effects on performance. Industrial Marketing Management, 34, 187-202.

Senge, P. (1990). The fifth discipline. New York, NY: Doubleday.

Sinkula, J. M. (1994). Market information processing and organizational learning. Journal of Marketing, 1, 35-45.

Slater, S. F., \& Narver, J. C. (1995). Market orientation and the learning organization. Journal of Marketing, 59, 63-74.

Slater, S. F., \& Narver, J. C. (1996). Competitive strategy in the market-focused business. Journal of Market-Focused Management, 1, 159-174.

Slater, S. F., \& Olson, E. M. (2001). Marketing's contribution to the implementation of competitive strategy: An empirical analysis. Strategic Management Journal, 22, 1055-1067.

Sørensen, H. E. (2009). Why competitors matter for market orientation. European Journal of Marketing, 43, 735-761.

Tortosa, V., Miguel, M., \& Javier, s (2009). Internal market orientation and its influence on organisational performance. European Journal of Marketing, 43, 1435-1456.

Tsai, K.-H., Chou, C., \& Kuo, J. J.-H. (2007). The curvilinear relationships between responsive and proactive market orientations and new product performance: A contingent link. Industrial Marketing Management, 37, 884-894.

Verona, G. (1999). A resource-based view of product development. Academic Management Review, 24, 132-142.

Voola, R., \& O'Cass, A. (2010). Implementing competitive strategies: The role of responsive and proactive market orientations. European Journal of Marketing, 44, 245-266.

Wernerfelt, B. (1984). A resource-based view of the firm. Strategic Management Journal, 5, 171-180.

Zhang, J., \& Duan, Y. (2010). The impact of different types of market orientation on product innovation performance: Evidence from Chinese manufacturers. Management Decision, 48. 